\title{
Paediatric non-infectious uveitis in Cape Town, South Africa: a retrospective review of disease characteristics and outcomes on immunomodulating treatment
}

Waheba Slamang ${ }^{1,2^{*}}$, Christopher Tinley ${ }^{2,3}$, Nicola Brice ${ }^{1,2}$ and Christiaan Scott ${ }^{1,2^{*}}$ (D)

\begin{abstract}
Background: Non-infectious uveitis is a well-reported cause of blindness in more developed countries, however data from sub-Saharan Africa is lacking. Here we aim to describe the diseases associated with paediatric noninfectious uveitis and the effect of currently available treatment in this setting.

Methods: A retrospective observational analysis of children with non-infectious uveitis from January 2010 to December 2017, attending the tertiary paediatric rheumatology and ophthalmology referral units in Cape Town was conducted. Statistical analysis utilising STATA13 software was performed with $p<0.05$ considered significant.

Results: Twenty-nine children were identified: median age at first visit of 74 months (IQR 49-86 months), female to male ratio of 0.9:1, predominantly of mixed ancestry (72.4\%). Juvenile idiopathic arthritis associated uveitis (JIAU) (48.3\%), idiopathic uveitis (41.4\%), sarcoidosis (6.9\%) and Behcet's disease (3.5\%) were diagnosed. Chronic anterior uveitis (72.4\%) was the most frequent finding. Fifty-five percent had complications at presentation and all children with idiopathic uveitis presented with cataracts.

Only 6.5\% of the JIA cohort had JIAU. All JIA children had chronic anterior uveitis. There were no differences between JIA children with uveitis and those without uveitis, for sex $(p=0.68)$ and race $(p=0.58)$. Significantly, children with uveitis presented at an overall younger age $(p=0.008)$, had oligo-articular JIA $(p=0.01)$ and were antinuclear antibody positive $(p<0.001)$.

Children with idiopathic uveitis were predominantly male (66.6\%) with chronic anterior uveitis (41.7\%).

Nineteen children (65.5\%) in the cohort had inactive disease on treatment at 12 months from diagnosis, which included 10 on topical corticosteroid therapy. At the last clinical visit 17 (58.6\%) on standard initial therapy, 8 (27.6\%) on tumour necrosis factor inhibitors and 2 on additional DMARDs were in remission. Five of these children still required topical corticosteroids. Surgery was performed in $41.4 \%$, primarily in the idiopathic group. Visual acuity improved or was maintained on treatment.

(Continued on next page)
\end{abstract}

\footnotetext{
*Correspondence: waheba.slamang@gmail.com; chris.scott@uct.ac.za

'Department of Paediatric Rheumatology, Red Cross War Memorial Children's Hospital, Klipfontein Rd, Cape Town 7700, South Africa

Full list of author information is available at the end of the article
}

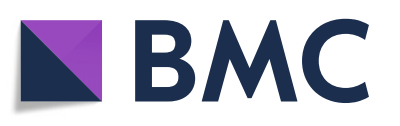

(- The Author(s). 2021 Open Access This article is licensed under a Creative Commons Attribution 4.0 International License, which permits use, sharing, adaptation, distribution and reproduction in any medium or format, as long as you give appropriate credit to the original author(s) and the source, provide a link to the Creative Commons licence, and indicate if changes were made. The images or other third party material in this article are included in the article's Creative Commons licence, unless indicated otherwise in a credit line to the material. If material is not included in the article's Creative Commons licence and your intended use is not permitted by statutory regulation or exceeds the permitted use, you will need to obtain permission directly from the copyright holder. To view a copy of this licence, visit http://creativecommons.org/licenses/by/4.0/. The Creative Commons Public Domain Dedication waiver (http://creativecommons.org/publicdomain/zero/1.0/) applies to the data made available in this article, unless otherwise stated in a credit line to the data. 
(Continued from previous page)

Conclusion: Current practice seems to detect children with potentially sight-threatening disease but the high rate of complications and the low percentage of children with JIAU raises concerns of delayed healthcare intervention.

Tumour necrosis factor inhibitors have improved outcomes in refractory cases in this cohort, however further studies are needed.

Keywords: Non-infectious uveitis children juvenile idiopathic arthritis sub-Saharan Africa

\section{Background}

Uveitis broadly describes inflammation of the iris, choroid and retina, which occurs when the blood-aqueous and blood-retinal barrier is disrupted. This may be triggered by infectious or non-infectious diseases and is an important cause of $16-25 \%$ of blindness worldwide. The estimated paediatric prevalence of $28: 100000$, is at least 4 times lower than in adults [1]. However, the sightthreatening consequences due to late presentation and aggressive disease are far-reaching in children, particularly in developing countries where employment opportunities for the visually impaired are limited [2].

Epidemiology studies highlight the paucity of data from Africa and other developing countries, noting potential differences in the prevalence and demographics of underlying aetiologies as well as in outcomes $[1,3]$. In subSaharan African countries (SSA), uveitis is under-reported in surveys or studies on blindness in specific regions. In general, active uveitis resulting in visual loss tends to be documented and outcomes, rather than the underlying diseases are recorded [4-8]. Additionally, studies predominantly describe adult populations and infectious diseases [9-12]. In children, post-streptococcal syndrome and HIV-associated uveitis have also recently been described [13-15]. Idiopathic uveitis is diagnosed where an underlying systemic cause cannot be found despite diagnostic ocular paracentesis in some cases. This frequently presents with complications and still accounts for up to 50\% of uveitis populations seen at referral centres [16-18].

The prevalence of paediatric immune-mediated systemic diseases and the associated uveitis, varies by underlying disease, disease subtype, as well as geographically [1]. In SSA, the limited data in children, describe the association with juvenile idiopathic arthritis (JIA). Notably BD is reported more frequently from countries around the Mediterranean basin and the Far East [1, 19-26]. In European and western countries, where the highest prevalence of JIA is reported, chronic anterior uveitis occurs in up to $20 \%$ of children diagnosed with the oligo-articular JIA subtype. These are predominantly ANA positive, young girls under 7 years old of Caucasian ancestry although recently, associations with age and sex have been questioned [27, 28]. Ancestry as a predictor of more aggressive disease and poorer outcomes has also been described but research in this area is ongoing [29]. While chronic anterior uveitis is associated with the psoriatic JIA subtype, acute anterior uveitis may also be seen in those presenting at an older age with an enthesitis-related arthritis phenotype [30, 31]. However, acute anterior uveitis is more commonly associated with enthesitis-related arthritis and psoriatic JIA, as well as in other HLA B27 associated diseases [27, 32].

The potential risk of amblyopia and poor long-term outcomes secondary to persistent disease activity and prolonged corticosteroid treatment in children is recognized. The standard uveitis nomenclature (SUN) working group classification and screening guidelines, though not formally validated in children, has improved crossstudy comparisons. This has aided monitoring of treatment responses and decisions to escalate therapy. Informed by ongoing studies, treatment recommendations are further elaborated in recent management guidelines. [33-46].

Understanding the underlying causes of noninfectious, immune-mediated uveitis is essential for appropriate management and to improve overall visual outcomes. However, to date there are no studies reviewing non-infectious uveitis per se, in children from SSA.

\section{Aim}

Here we aim to describe the disease characteristics and outcomes on immunomodulatory treatment, of children with non-infectious uveitis managed at a tertiary paediatric referral centre in Cape Town, South Africa.

\section{Methods \\ Study design}

A retrospective case file review of all children $\leq 16$ years managed for non-infectious uveitis by the paediatric ophthalmology and rheumatology units in Cape Town from 1 January 2010 to 31 December 2017 was conducted.

The tertiary paediatric rheumatology and ophthalmology referral units at Groote Schuur and Red Cross Children's Hospitals in Cape Town are the main tertiary referral centres for the Western Cape as well as other provinces in South Africa. The Western Cape population numbers around 6.2 million and children <15years constitute $26 \%$ [47]. For the purposes of this study, selfreported ancestry is considered, as associations with 
potentially higher risk and poorer outcomes have been described $[28,29]$.

\section{Data collection}

Children with non-infectious uveitis managed by the tertiary referral paediatric ophthalmology and rheumatology units were included. Children with JIA were included if uveitis was found on screening during the study period. Screening for JIAU was performed at diagnosis and at 3 monthly intervals as per the Standard Uveitis Nomenclature (SUN) working group recommendations $[34,48]$. Children were identified from a review of paediatric rheumatology (PR) and ophthalmology case files and confirmed on the hospital electronic booking system. Data of patients identified with non-infectious uveitis included age, sex, self-reported ancestry, date of first presentation, anatomical location of uveitis, visual acuity, (VA) and complications. For uniformity, VA was converted from the recorded annotation to the log of the minimal angle of resolution (LogMAR) [49]. Data of children with JIA additionally included JIA subtype, time to uveitis diagnosis and arthritis disease activity on treatment.

JIA was defined as per International League of Associations for Rheumatology criteria [50]. Idiopathic uveitis was diagnosed after exclusion of infective and other immune mediated diseases by clinical assessment and laboratory tests. These included but were not limited to toxocara and toxoplasma serology, HIV Elisa or polymerase chain reaction (PCR), ANA, anti-double stranded DNA, anti-streptolysin O (ASO) and, antideoxyribonuclease B (Anti-DNAse B) titres, serum angiotensin converting enzyme, Treponema Pallidum Haemagglutination test and/or Venereal Disease Research Laboratory test and urine dipstix. Ebstein barr virus, cytomegalovirus and Lyme disease (not endemic in the Western Cape region of South Africa) serology, were not routinely requested but may have been performed in individual cases. Sarcoidosis was diagnosed based on clinical presentation, histology +/- raised serum angiotensin levels and Behcet's disease by clinical diagnosis as per the paediatric BD criteria 2015 [51].

Treatment modalities were grouped as standard initial treatment which included corticosteroids (topical and/or systemic) and methotrexate $10-20 \mathrm{mg} / \mathrm{m}^{2}$ (maximum dose $20 \mathrm{mg}$ orally or $25 \mathrm{mg}$ subcutaneously). Additional disease modifying anti-rheumatic drug therapy included azathioprine $(1-3 \mathrm{mg} / \mathrm{kg})$ and mycophenolate mofetil $\left(250-500 \mathrm{mg} / \mathrm{m}^{2}\right.$ bd). Biologic therapy included TNFi Infliximab $6-10 \mathrm{mg} / \mathrm{kg}$ iv infusion monthly (after loading) and Adalimumab 20-40 mg subcutaneously every second week.

The primary outcome was considered as clinically inactive disease on treatment. Ophthalmology assessments were performed at weekly to 3-monthly intervals depending on severity of disease. Uveitis activity at 12 months and at the last clinical visit was evaluated. Anterior chamber disease, vitreous haze and posterior disease were assessed utilising the SUN criteria [34]: The response to treatment was defined as a two-step decrease in inflammation or decrease to Grade 0, active disease as $\geq$ Grade 1 (6-15 cells/slit lamp field and faint anterior chamber flare), inactive disease as Grade $0(<1$ cell/slit lamp field and no anterior chamber flare) and worsening of disease activity as a two-step increase in level of inflammation or an increase from $3+$ to $4+$ for anterior chamber disease. Vitreous haze was further evaluated by the Nussenblatt 1985 criteria [52] and posterior disease activity by resolution or non-resolution of retinal vasculitis and/or disc swelling.

For this study, remission was defined as $\geq 3$ months of inactive disease on treatment.

The secondary outcome was considered as improvement in visual acuity.

Children managed for $<3$ months or were lost to follow-up, as well as children with proven infectious uveitis were excluded from the study.

\section{Statistical analysis}

Statistical analysis was performed using STATA13 software.

The frequencies of categorical variables were noted and descriptive statistics employed to determine measures of central tendency. Chi-squared (or Fisher exact tests if frequencies were $<5$ ) and t-tests (or Wilcoxon sum rank tests for non-parametric data) for comparisons between groups, were used as appropriate to evaluate associations with $p<0.05$ considered significant. Odds ratios for statistically significant variables were calculated to evaluate associated risk. Cox regression models was used to assess time to inactive disease and time to uveitis from JIA diagnosis.

\section{Results}

Thirty-four children were referred for the management of uveitis. 19 (55.9\%) presented to ophthalmology and 15 $(44.1 \%)$ to rheumatology. Five with underlying infectious causes were excluded, resulting in 29 children meeting inclusion criteria. The overall group had a 0.9:1 female to male ratio, median age at first visit of 74 months (IQR 49-86 months) and were predominantly of mixed ancestry $(72.4 \%)$. Children with JIAU (48.3\%) and idiopathic uveitis (41.4\%) most commonly had bilateral, chronic anterior uveitis (72.4\%). Panuveitis (33.4\%), acute anterior $(6.9 \%)$ and intermediate uveitis $(3.5 \%)$ were less frequent. All children with panuveitis had inflammation of the anterior chamber and vitreous, with retinal vasculitis 
and/or disc swelling. Fifty-five percent had cataracts at presentation (Table 1).

For the cohort, the median time from diagnosis to inactive disease was 7 months (IQR 6-15 months) (Fig. 1a). Although the median time varied depending on the underlying disease, there was no statistical difference $(p=0.28)$ between children with JIAU and idiopathic uveitis for overall time to inactive disease from diagnosis (Fig. 1b). Twenty children were diagnosed before 2017. Of these, 19 children had inactive disease on treatment at time-point 12 months after diagnosis, including 3 who had been started on TNFi (Fig. 2). 8 children in the standard treatment group and 1 on TNFi, no longer required topical steroid therapy. At the last clinical visit, 27 (93.1\%) children were in remission. One (3.5\%) had ongoing refractory

Table 1 Disease characteristics

\begin{tabular}{|c|c|c|c|c|}
\hline Diagnosis & JIAU & Idiopathic & Sarcoidosis & Behcet's Disease \\
\hline $\begin{array}{l}\text { Total N (\%) } \\
\text { (Cl: } 1.4-2.0)\end{array}$ & $\begin{array}{l}N=14 \\
(48.3)\end{array}$ & $\begin{array}{l}N=12 \\
(41.3)\end{array}$ & $\begin{array}{l}N=2 \\
(6.9)\end{array}$ & $\begin{array}{l}N=1 \\
(3.5)\end{array}$ \\
\hline $\begin{array}{l}\text { No. of affected eyes } \\
\text { (Cl: 1.6-1.9) }\end{array}$ & 26 & 20 & 4 & 1 \\
\hline \multicolumn{5}{|l|}{ Demographics } \\
\hline \multicolumn{5}{|l|}{ Presentation age (months) } \\
\hline $\begin{array}{l}\text { Median (IQR) } \\
\text { (Cl: 62.6-87.8) }\end{array}$ & $55(34-86)$ & $76.5(67-85)$ & $102.5(49-156)$ & $120(-)$ \\
\hline $\begin{array}{l}\text { Female N (\%) } \\
(\mathrm{Cl}: 1.3-1.7)\end{array}$ & $8(57.1)$ & $4(33.3)$ & $2(100)$ & 0 \\
\hline \multicolumn{5}{|l|}{$\begin{array}{l}\text { Ancestry N (\%) } \\
(\mathrm{Cl}: 1.1-1.6)\end{array}$} \\
\hline Mixed & $10(71.4)$ & $9(75)$ & $1(50)$ & $1(100)$ \\
\hline Black African & $2(14.3)$ & $2(16.7)$ & $1(50)$ & 0 \\
\hline Caucasian & $2(14.3)$ & $1(8.3)$ & 0 & 0 \\
\hline \multicolumn{5}{|l|}{$\begin{array}{l}\text { Anatomical Location } \\
\text { (Cl: } 1.3-2.2 \text { ) }\end{array}$} \\
\hline Acute Anterior & 0 & 1 & 1 & 0 \\
\hline Chronic Anterior & 14 & 6 & 0 & 1 \\
\hline Intermediate & 0 & 1 & 0 & 0 \\
\hline Posterior & 0 & 0 & 1 & 0 \\
\hline Panuveitis & 0 & 4 & 0 & 0 \\
\hline \multicolumn{5}{|l|}{ Laterality N (\%) } \\
\hline Unilateral & 2 & 4 & 0 & 1 \\
\hline Bilateral & 12 & 8 & 2 & 0 \\
\hline \multicolumn{5}{|l|}{$\begin{array}{l}\text { Complications } \\
\text { (Cl 1.0-1.9) }\end{array}$} \\
\hline No. affected children (N) & 7 & 9 & 0 & 0 \\
\hline Cataracts & 5 & 9 & 0 & 0 \\
\hline Posterior synechiae & 3 & 3 & 0 & 0 \\
\hline Band Keratopathy & 2 & 2 & 0 & 0 \\
\hline Raised intra- ocular pressure & 3 & 4 & 0 & 0 \\
\hline \multicolumn{5}{|l|}{ VA at presentation (Median) } \\
\hline$(\mathrm{IQR}) \stackrel{\log M A R(\mathrm{IQR})}{ }$ & $0.1(0.0-0.3)$ & $0.95(0.55-2.45)$ & $0.0(0.0-0.0)$ & $0.3(-)$ \\
\hline \multicolumn{5}{|l|}{ VA at last visit } \\
\hline Median LogMAR (IQR) & $0(0.0-0.2)$ & $0.3(0.0-0.6)$ & $0(0-0)$ & $0.1(-)$ \\
\hline Change in VA: $p$-value & 0.06 & 0.001 & - & - \\
\hline
\end{tabular}


a

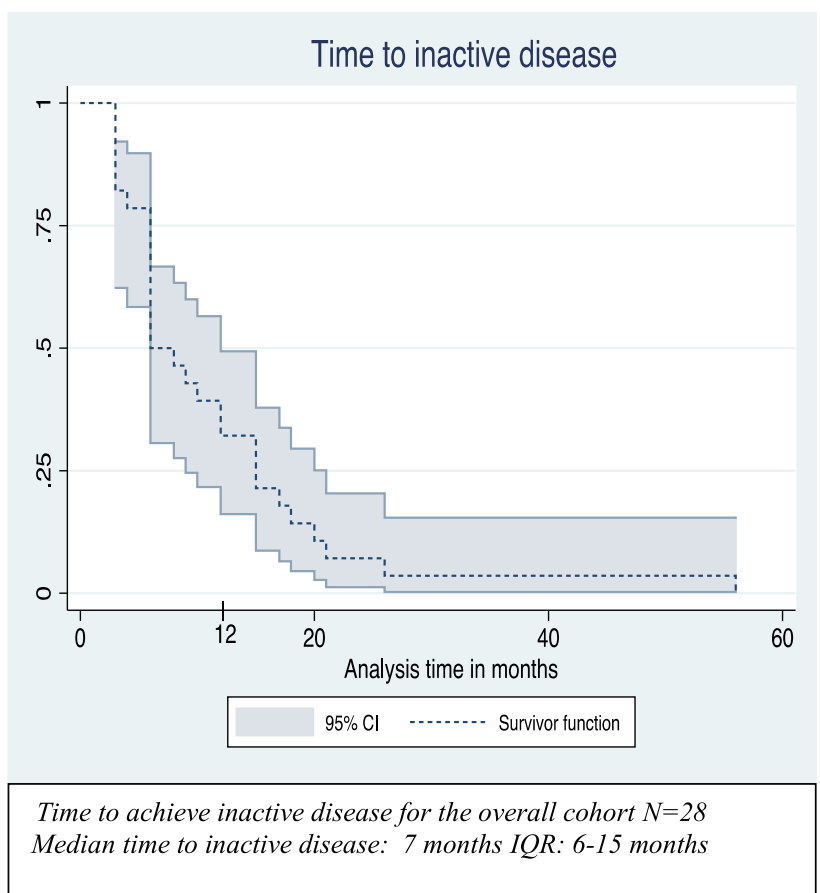

b

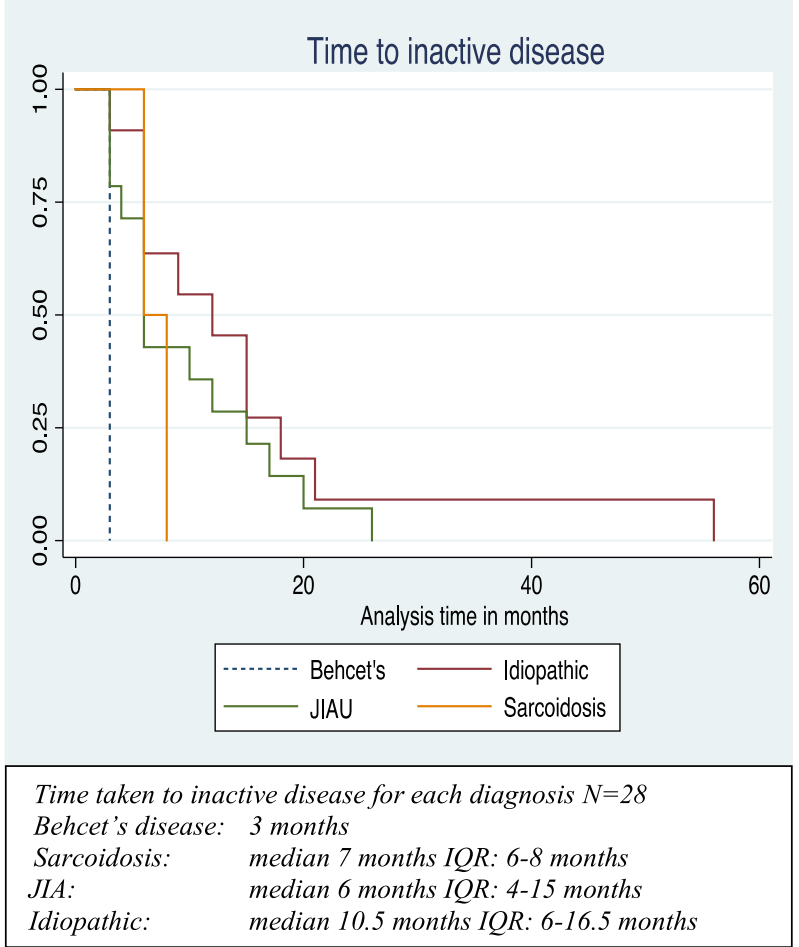

Fig. 1 a: Time to inactive disease. b: Time to inactive disease by diagnosis

disease and 1 (3.5\%) had clinically inactive disease for $<3$ months (Table 2). Twenty-two children no longer required topical steroid therapy. However, 2 children recently diagnosed with JIAU in the standard treatment group and 3 with idiopathic uveitis in the TNFi group, still required topical steroid therapy.

There was an overall clinical improvement in visual acuity (VA) (Table 1).

\section{Disease characteristics}

Children with JIAU were most commonly female (female to male ratio of 1:0.75), had a median age of 55 months (IQR 34-86 months), and were predominantly of mixed ancestry $(71.4 \%)$. All children had chronic anterior uveitis (100\%).

Further analysis in relation to the overall JIA cohort managed during the study period was undertaken (Table 3). A total of 229 patients were assessed for JIA of which 12 were excluded according to ILAR criteria. The remaining 217 were evaluated, with a consequent JIAU clinic prevalence of $6.5 \%$. Three children had uveitis for 12, 9 and 4 months prior to the diagnosis of JIA. The majority developed uveitis within a year of diagnosis (Fig. 3). Comparisons for sex $(p=0.68)$ and ancestry $(p=0.58)$ were not statistically significant. Children older than 144 months were not diagnosed $(p=0.01)$ with uveitis. Young age $\leq 84$ months $(p=0.01)$, oligo-JIA subtype $(p=0.01)$ and positive ANA $(p<0.001)$ were significant factors. Univariate analysis showed odds ratios (OR) for possible risk factors associated with uveitis as oligoarticular subtype (OR $4.45 \mathrm{CI} 1.35-14.7$ ) and positive ANA (OR 33.3, CI 6.83-162.09). Seven (50\%) children had complications. Reduced VA at presentation was due to cataracts in 5 children. There was no statistical difference in complications between those diagnosed with uveitis before arthritis and those with uveitis on screening at diagnosis and subsequently $(p=0.28)$. At timepoint 12 months from diagnosis, 9 (64.3\%) children on standard initial treatment and one on TNFi had inactive disease. By the end of the study period, 8 (57.1\%) were in remission on standard initial treatment, 2 (14.3\%) on additional DMARDs and the previously refractory 4 (28.6\%) on TNFi treatment. Of children treated with TNFi, 3 were originally commenced on infliximab and 2 were switched to adalimumab due to lack of efficacy. Of these, one was diagnosed with uveitis 12 months before arthritis. The one child on infliximab and all children in the adalimumab group achieved remission. Three children had cataract surgery.

Idiopathic uveitis (41.4\%) was the next frequent diagnosis, presenting in males $(66.6 \%)$, at a median age of 76.5 months (IQR 49-156 months) who were of of 


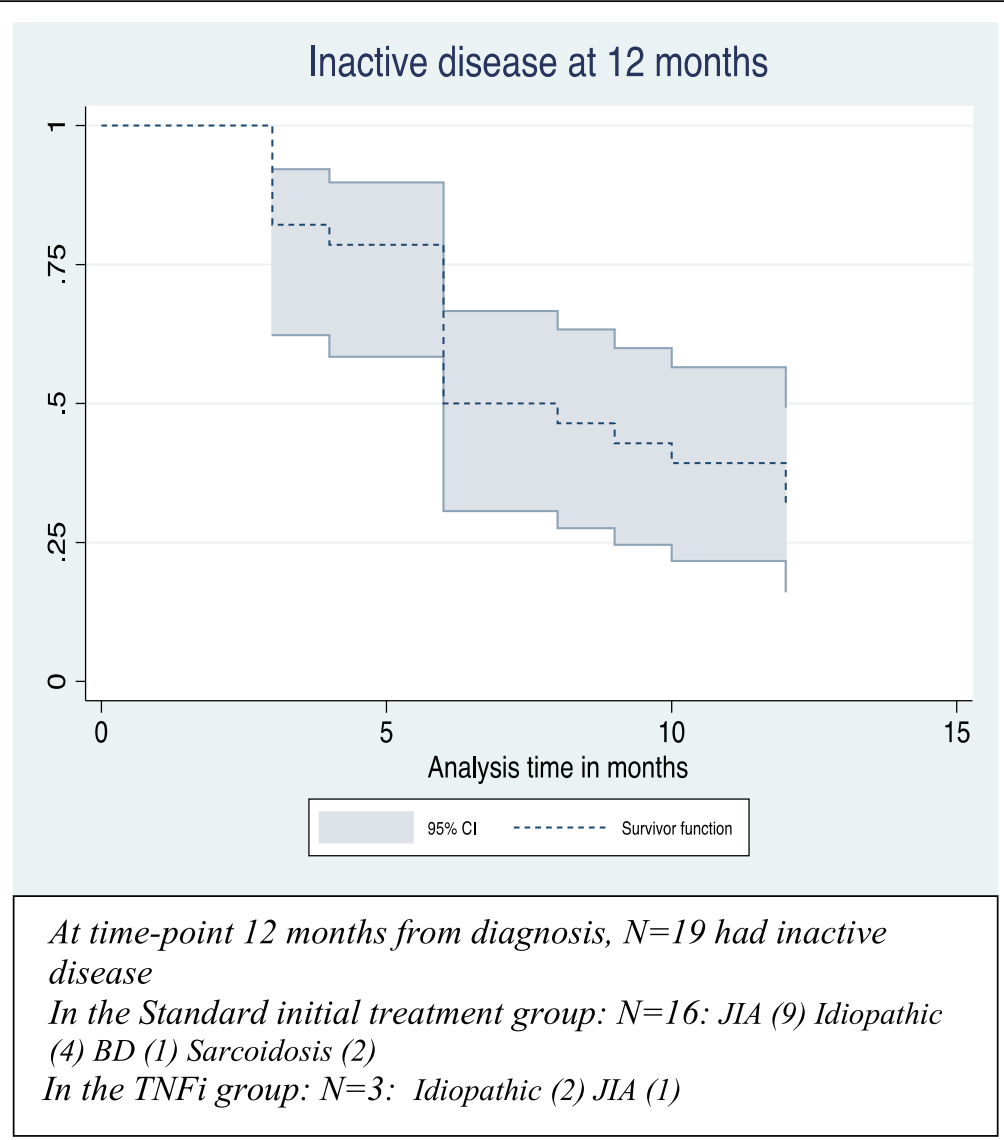

Fig. 2 Inactive disease at 12 months

Table 2 Treatment

\begin{tabular}{|c|c|c|c|c|c|c|c|c|}
\hline \multirow[t]{2}{*}{ Treatment } & \multirow{2}{*}{$\begin{array}{l}\text { Total } \\
\text { treated } \\
\mathrm{N}\end{array}$} & \multirow{2}{*}{$\begin{array}{l}\text { Response } \\
\text { (R) / No } \\
\text { Response } \\
\text { (NR) }\end{array}$} & \multicolumn{2}{|c|}{ JIAU $N=14$} & \multirow{2}{*}{$\begin{array}{l}\text { Idiopathic } \\
N=12\end{array}$} & \multirow{2}{*}{$\begin{array}{l}\text { Sarcoidosis } \\
N=2\end{array}$} & \multirow{2}{*}{$\begin{array}{l}\text { Behcet's } \\
\text { Disease } \\
N=1\end{array}$} & \multirow{2}{*}{$\begin{array}{l}\text { Total N } \\
\text { (\%) }\end{array}$} \\
\hline & & & $\begin{array}{l}\text { Screening } \\
N=11\end{array}$ & Pre-JIA diagnosis $N=3$ & & & & \\
\hline \multirow[t]{2}{*}{ Standard Initial Rx } & 29 & $R$ & 7 & 1 & 6 & 2 & 1 & $17(58.6)$ \\
\hline & & NR & 4 & 2 & 6 & 0 & 0 & $12(41.4)$ \\
\hline \multirow[t]{2}{*}{ Azathioprine } & 8 & R & 1 & - & 0 & - & - & $1(12.5)$ \\
\hline & & NR & 3 & - & 4 & - & - & $7(87.5)$ \\
\hline \multirow[t]{2}{*}{ Mycophenolate Mofetil } & 3 & R & 1 & - & 0 & - & - & $1(33.3)$ \\
\hline & & NR & 1 & - & 1 & - & - & $2(66.6)$ \\
\hline \multirow[t]{2}{*}{ Infliximab } & 6 & R & 1 & 0 & 1 & - & - & $2(33.3)$ \\
\hline & & NR & 1 & 1 & 1 & - & - & $3(50)$ \\
\hline \multirow[t]{2}{*}{ Adalimumab } & 8 & R & 1 & 2 & 4 & - & - & $7(87.5)$ \\
\hline & & NR & 0 & 0 & 1 & - & - & $1(12.5)$ \\
\hline \multicolumn{3}{|c|}{ Surgery: no. of children N (\%) } & 2 & 1 & 9 & 0 & 0 & $12(41.4)$ \\
\hline \multicolumn{9}{|l|}{ No. of procedures } \\
\hline \multicolumn{3}{|c|}{ Cataract incl. Pars planar vitrectomy/ lensectomy } & 2 & 1 & 10 & 0 & 0 & 13 \\
\hline \multicolumn{3}{|l|}{ Corneal chelation } & 0 & 0 & 2 & 0 & 0 & 2 \\
\hline \multicolumn{3}{|l|}{ Evisceration } & 0 & 0 & 1 & 0 & 0 & 1 \\
\hline
\end{tabular}

Responders (R) had inactive disease on treatment. In non-responders (NR), treatment was escalated to one of the additional DMARDs then a TNFi or directly to a TNFi 
Table 3 Comparison of JIA with no uveitis and with uveitis (JIAU)

\begin{tabular}{|c|c|c|c|c|c|}
\hline Diagnosis & JIA Total $N=217$ & JIA no uveitis $N=203$ & JIAU $N=14$ & $p$-value & \\
\hline $\begin{array}{l}\text { Median Age months } \\
\text { (IQR) }\end{array}$ & $\begin{array}{l}111 \\
(54-148)\end{array}$ & $\begin{array}{l}114.5 \\
(59-152)\end{array}$ & $\begin{array}{l}55 \\
(34-86)\end{array}$ & $t p=0.008$ & \\
\hline Age groups (months) N (\%) & & & & & Odds Ratio $95 \% \mathrm{Cl}$ \\
\hline $0-84$ & $70(32.3)$ & $60(29.6)$ & $10(71.4)$ & $\dagger p=0.01$ & $0.46 \mathrm{Cl} 0.25-0.83$ \\
\hline $85-144$ & $73(33.6)$ & $69(33.9)$ & $4(28.6)$ & $p=0.78$ & $0.71 \mathrm{Cl} 0.22-2.35$ \\
\hline $145-192$ & $60(27.7)$ & $60(29.6)$ & 0 & $+p=0.01$ & $1.0 \mathrm{Cl} 0.6-1.7$ \\
\hline Female N (\%) & $135(62.2)$ & $127(62.5)$ & $8(57.1)$ & $p=0.68$ & $0.78 \mathrm{Cl} 0.26-2.34$ \\
\hline \multicolumn{6}{|l|}{ Ancestry N (\%) } \\
\hline Mixed & $124(57.1)$ & $114(56.2)$ & $10(71.4)$ & $p=0.40$ & $0.72 \mathrm{Cl} 0.39-1.3$ \\
\hline Black African & $37(17.1)$ & $35(17.2)$ & $2(14.3)$ & $p=1.00$ & $1.25 \mathrm{Cl} 0.27-5.8$ \\
\hline Caucasian & $56(25.8)$ & $54(26.6)$ & $2(14.3)$ & $p=0.53$ & $0.46 \mathrm{Cl} 0.10-2.1$ \\
\hline \multicolumn{6}{|l|}{ JIA subtype $N(\%)$} \\
\hline Oligo-articular & $83(38.3)$ & $73(35.9)$ & $10(71.5)$ & $+p=0.01$ & $4.45 \mathrm{Cl} 1.35-14.7$ \\
\hline Poly articular RF + & $18(8.3)$ & $18(8.8)$ & 0 & $p=0.61$ & $0.08 \mathrm{Cl} 0.04-0.13$ \\
\hline Poly articular RF - & $43(19.8)$ & $40(19.7)$ & 3 & $p=1.00$ & $1.05 \mathrm{Cl} 0.54-2.04$ \\
\hline Psoriatic & $16(7.4)$ & $15(7.4)$ & 1 & $p=1.00$ & $0.99 \mathrm{Cl} 0.59-1.66$ \\
\hline Systemic Onset JIA & $17(7.8)$ & $17(8.4)$ & 0 & $p=0.61$ & - \\
\hline Enthesitis Related Arthritis & $38(17.5)$ & $38(18.7)$ & 0 & $p=0.14$ & - \\
\hline Undifferentiated & $2(0.9)$ & $2(1)$ & 0 & $p=1.00$ & - \\
\hline \multicolumn{6}{|l|}{ Lab Parameters N (\%) } \\
\hline ANA tested & $147(67.7)$ & $136(67)$ & $11(78.6)$ & $+p<0.001$ & $33.29 \mathrm{Cl} 6.83-162.09$ \\
\hline Hep2 Positive & 15 & 10 & 5 & & \\
\hline Elisa Positive & 15 & 9 & 6 & & \\
\hline RF tested & $125(57.6)$ & $116(57.1)$ & $9(64.3)$ & $p=0.36$ & - \\
\hline Negative & 107 & 98 & 9 & & \\
\hline Positive & 18 & 18 & 0 & & \\
\hline $\begin{array}{l}\text { HLA B27 tested } \\
\text { Present }\end{array}$ & $\begin{array}{l}63(29) \\
4\end{array}$ & $\begin{array}{l}62(30.5) \\
4\end{array}$ & $\begin{array}{l}1(7.1) \\
0\end{array}$ & $p=1.00$ & - \\
\hline
\end{tabular}

mixed ancestry (75\%). Both eyes were affected in $66.6 \%$ with chronic anterior uveitis (50\%). All children presented with cataracts and had a median VA LogMAR $0.95(0.55-2.45)$. Four children (33.3\%) had inactive disease on standard initial treatment and $2(16.7 \%)$ on TNFi at 12 months. At the last clinical visit, $6(50 \%)$ were in remission on standard initial treatment, 1 (8.3\%) on infliximab and $4(33.3 \%)$ on adalimumab. $75 \%$ of children required cataract surgery. One child did not respond to therapy, was ANA positive and needed evisceration of one eye due to painful glaucoma. The overall improvement in VA for the remaining children was statistically significant $(p=0.001)$.

Sarcoidosis (6.9\%) was diagnosed in 2 females. Both had bilateral uveitis and no complications at presentation. They had inactive disease by 12 months, achieved remission on standard initial therapy and had preserved vision.
The 120 month old male of mixed ancestry with BD, presented with unilateral chronic anterior uveitis, had no complications and responded to standard therapy within 3 months.

\section{Discussion}

Non-infectious immune-mediated uveitis remains an important cause of ocular morbidity in children and despite some advances in the understanding of the underlying pathophysiology, sight-threatening complications are still frequently reported [53, 54]. The dearth of literature from Africa and other developing countries, reinforces the perception that immune-mediated diseases are rare or non-existent in children from this setting. Although this assumption has recently been challenged [55-58], advocacy for treatment strategies deemed too expensive, regardless of proven efficacy elsewhere, is still hindered. 


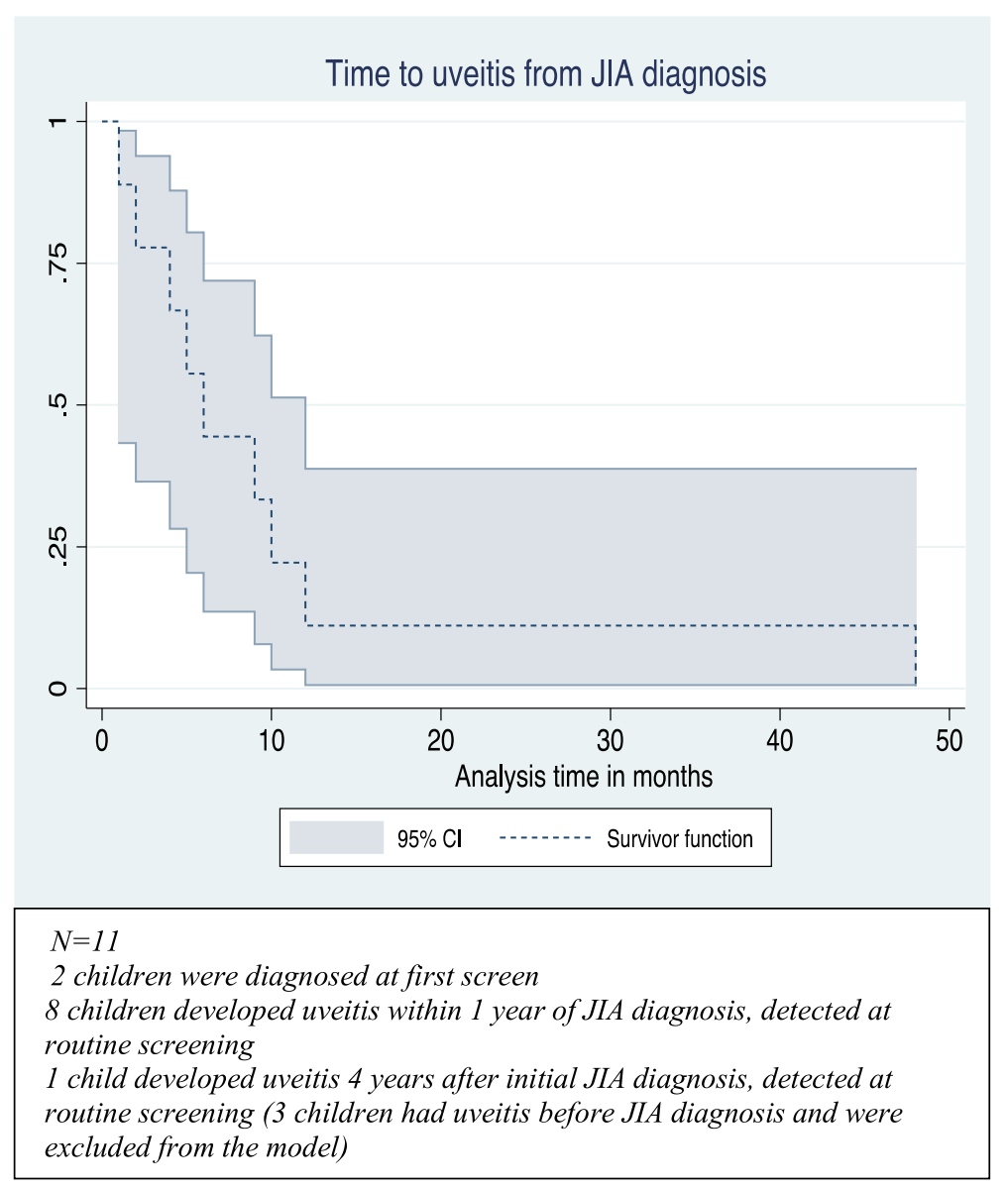

Fig. 3 Time to uveitis from JIA diagnosis

Here, we have shown that the spectrum and disease characteristics associated with non- infectious uveitis are comparable in some respects to that of more developed countries but are dissimilar to reports from North Africa, where $\mathrm{BD}[24,25]$ is more common. Importantly,
$54.5 \%$ of our cohort presented with easily identifiable cataracts and posterior synechiae, attesting to significant delays in diagnosis. The inequitable distribution of health care resources, socioeconomic factors, health seeking behaviour and lack of expertise in key areas,

Table 4 Comparison of SSA and developed countries

\begin{tabular}{|c|c|c|c|c|c|c|c|}
\hline Country & Current study: South Africa & $\begin{array}{l}\text { South Africa } \\
\text { (14) }\end{array}$ & $\begin{array}{l}\text { Zambia } \\
\text { (20) }\end{array}$ & Kenya (63) & Nigeria (21) & Canada (61) & Atlanta (27) \\
\hline Single / Multi-centre & Single & Single & Single & Single & Single & Multi & Single \\
\hline Total N & 217 & 97 & 85 & 68 & 28 & 1183 & 287 \\
\hline \multicolumn{8}{|l|}{ JIA subtypes (\%) } \\
\hline Oligo & 38.3 & 39 & 32.1 & 23.5 & 39.3 & 40 & 46 \\
\hline Poly RF- & 19.8 & 30 & 34.6 & 38.2 & 42.8 & 20 & 24.4 \\
\hline Poly RF+ & 8.3 & 9 & 11.5 & 17.6 & 7.1 & 4 & 4.5 \\
\hline ERA & 17.5 & 5 & 6.4 & 5.9 & 0 & 14 & 12.9 \\
\hline Psoriatic & 7.4 & 0 & 1.3 & 0 & 0 & 6 & 3.5 \\
\hline SJIA & 7.8 & 16 & 14.1 & 14.7 & 17.9 & 6 & 7.7 \\
\hline Undifferentiated & 0.9 & 0 & 0 & 0 & 0 & 10 & 0.7 \\
\hline Uveitis (\%) & 6.5 & 4 & 12.8 & 1.5 & 7.1 & 8.5 & 18.2 \\
\hline
\end{tabular}


contribute in varying degrees to delayed access to care in South Africa and likely resulted in late presentation to our unit $[59,60]$.

\section{Juvenile idiopathic Arthritis}

Comparison with two studies from developed countries (Table 4), the large multicentre Canadian Research in Arthritis in Canadian Children emphasizing Outcomes (ReaCCH-out) study cohort and a single centre Atlanta study [27, 61], showed similarities in median age of JIA presentation, relative frequencies of poly-articular RF negative JIA subtype and ANA positivity. However, an older age at JIAU presentation and a lower frequency of oligo-articular JIA is seen in our cohort. The prevalence of JIAU here $(6.5 \%)$ is also lower than reported in those studies $(8.5 \%$ and $18 \%)$, as well as other developed country descriptions of up to 20\% [62]. Paediatric rheumatology is a relatively new sub-speciality in South Africa, with a formal training program only established within the last 10 years. Under-recognition and lack of referral may play a role in the low frequency of JIA cases reported here. This seems to be in keeping with the few published studies from SSA [14, 20, 21, 63].

The chronic anterior uveitis, presenting at a younger mean age, significantly in the $\leq 84$-month age group ( $\mathrm{p}$ $=0.001$ ), also fits more developed country descriptions [62]. The majority of children with JIAU were ANA positive (78.6\%). However, this is in contrast to previous studies from South Africa, where children with uveitis had polyarthritis and were ANA negative [14, 19]. Whether ancestry has an influence on these differences is uncertain. Further prospective studies to elucidate the role of sex, ancestry, JIA subtype and positive ANA, is needed.

A high percentage $(21.4 \%)$, compared to the $3-7 \%$ generally described [48], developed uveitis before arthritis was diagnosed. Eleven were detected on screening and half presented with complications, $71.4 \%$ of which were cataracts. This raises further concerns of diagnostic delays in our setting. Notably, treatment was escalated to manage uveitis as arthritis was in remission.

\section{Idiopathic uveitis}

In our study, idiopathic uveitis (36.3\%) had a relatively lower frequency, reflecting the small number of referred patients likely for reasons as previously discussed. As in other descriptions, refractory disease with chronic anterior and panuveitis, complications and the need for surgery is noted. Similar severity and poorer outcome were reported in black South African children in historical studies [64-66], prior to the availability of TNFi. Here, children with refractory disease showed significant improvement in disease activity and VA on TNFi treatment.
Sarcoidosis is rare in children and may affect the uveal tract. Both children in our study responded well to systemic corticosteroid treatment and methotrexate. Escalation to TNFi was not needed here, as has been reported in other studies [67-71].

Paediatric BD is rarely reported from SSA although adult case series highlight severe skin and ocular manifestations [72, 73]. In contrast to paediatric case series from North Africa [24, 73], our patient had few recurrences, no complications and near normal vision at the last clinical assessment. HLAB51 was not done here.

Other immune mediated diseases including Vogt Koyanagi Harada syndrome, tubulointerstitial nephritis associated uveitis, uveitis with SLE and other autoinflammatory disorders were not represented in this study.

\section{Treatment outcome}

Overall, remission on standard initial uveitis treatment (58.6\%) endorses its use as first line therapy in our resource limited setting. Azathioprine and MMF were used less frequently due to gastrointestinal adverse effects and perceived lower efficacy. Neither cyclosporine nor intraocular corticosteroid injections were used in our cohort, as low evidence and side effect profile in young children were considered to outweigh the benefit $[37,46,74,75]$. TNFi were only used in refractory cases due to availability and cost and showed good efficacy. Infliximab has been shown to be safe and efficacious in children with refractory disease [76, 77]. Here, infliximab was successfully used in 2 patients, while one switched to adalimumab due to lack of efficacy and another due to an adverse reaction to the infliximab infusion. Adalimumab was used in conjunction with methotrexate in all our patients with good effect. The small sample size limits inferences that can be made from this study but previous studies [26, 39, 40,78] have shown good outcomes. The use of DMARDs and biologic therapy, allowed successful discontinuation of topical corticosteroid therapy in the majority of children. Further research into the efficacy of these agents in our setting is needed.

Five children with visually significant uveitic cataracts underwent lensectomies, together with pars plana vitrectomies (PPV), as is standard practice at our institution. This was due to the presence of associated vitritis or cyclitic membranes, which could only be removed by PPV.

\section{Selection bias}

Not all children with immune-mediated uveitis may have been referred, thus community prevalence is not reflected. Children with JIA are routinely assessed for uveitis screening and may be over-represented in this sample. 


\section{Limitations}

This retrospective case file review was dependent on the availability and accuracy of the medical records reviewed.

The small sample size limits inferences that can be made from these results.

\section{Conclusion}

Current practice seems to detect children with potentially sight-threatening non-infectious uveitis, however the low percentage of children with JIAU and the high rate of complications at presentation, raises concerns of delays in accessing appropriate healthcare. The use of DMARDs and tumour necrosis factor inhibitors in refractory cases, have improved outcomes in this cohort. Further prospective studies are needed to establish the role of associated risk factors, particularly in JIAU and the efficacy of TNFi.

\begin{abstract}
Abbreviations
ANA: Anti-nuclear antibody; ANA HEp2: Anti-nuclear antibody human epithelial cell indirect immuno- fluorescence test; AntiDNAse B: Antideoxyribonuclease B; ASOT: Anti-streptolysin O titres; BD: Behcet's disease; DMARDs: Disease modifying anti- rheumatic drugs; ERA: Enthesitis related arthritis; FHI: Fuch's heterochromic iridocyclitis; HIV: Human immunodeficiency virus; HLAB27: Human leukocyte antigen bB27; IL: Interleukin; ILAR: International league of associations for rheumatology; IQR: Interquartile range; ISG: International study group; JIA: Juvenile idiopathic arthritis; JIAU: Juvenile idiopathic arthritis associated uveitis; LogMAR: Log of the minimal angle of resolution; MMF: Mycophenolate mofetil; ReaCCH-out: Research in arthritis in Canadian children emphasizing outcomes; RF: Rheumatoid factor; SSA: Sub-Saharan Africa; SUN: Standard uveitis nomenclature; TB: Tuberculosis; TINU: Tubulo-interstitial nephritis associated uveitis; TNFi: Tumour necrosis factor inhibitors; VA: Visual acuity; VKH: Vogt Koyonagi Harada syndrome
\end{abstract}

\section{Acknowledgements}

We would like to thank Drs K. Webb, L. O'kongo, A. Fadmolela, Y. Fuseini, S. Akhalwaya and N. Freeman, as well as the administrative and nursing staff at Red Cross War Memorial Children's Hospital for their ongoing assistance in the management of our patients.

\section{Authors' contributions}

WS conceptualised the study, drafted the protocol, performed data collection, analysis, prepared and revised the manuscript. CT and NB provided diagnostic and management expertise and revised the final manuscript. CS supervised the study, reviewed the protocol, provided input and management expertise and revised the final manuscript. The author (s) read and approved the final manuscript.

\section{Funding}

This is a non-funded study.

\section{Availability of data and materials}

Privacy and confidentiality.

Data was anonymised and collected in accordance with the principles of Helsinki and GCP.

Data is stored in a password-protected database to which only the PI and sub-investigator has access.

The data is available from the corresponding authors upon reasonable request and is stored as part of the paediatric rheumatology database and repository at the University of Cape Town.

\section{Declarations}

\section{Ethics approval and consent to participate}

Ethics approval for data collection was obtained from the University of Cape Town human research ethics committee, HREC no: 692/2018.

\section{Consent for publication}

Not applicable.

\section{Competing interests}

WS has received sponsorships from Pfizer and Abbvie for conference attendance.

CS has received conference attendance sponsorships and speaker fees from Abbvie, Pfizer and Roche.

$C T$ and NB declare no competing interests.

\section{Author details}

'Department of Paediatric Rheumatology, Red Cross War Memorial Children's Hospital, Klipfontein Rd, Cape Town 7700, South Africa. ${ }^{2}$ University of Cape Town South Africa, Rondebosch, Cape Town, South Africa. ${ }^{3}$ Department of Paediatric Ophthalmology, Red Cross War Memorial Children's Hospital, Klipfontein Rd, Cape Town 7700, South Africa.

Received: 21 September 2020 Accepted: 17 March 2021

Published online: 01 April 2021

\section{References}

1. Tsirouki T, Dastiridou A, Symeonidis C, Tounakaki O, Brazitikou I, Kalogeropoulos C, Androudi S A focus on the epidemiology of Uveitis. Ocul Immunol Inflamm 2018;26(1):2-16. Available from: http://dx.doi.org/https:// doi.org/10.1080/09273948.2016.1196713

2. Bourne RRA, Flaxman SR, Braithwaite T, Cicinelli MV, Das A, Jonas JB, et al. Magnitude, temporal trends, and projections of the global prevalence of blindness and distance and near vision impairment: a systematic review and meta-analysis. Lancet Glob Health. 2017;5(9):e888-97. Available from: http:// www.sciencedirect.com/science/article/pii/S2214109X17302930. https://doi. org/10.1016/\$2214-109X(17)30293-0.

3. Miserocchi E, Fogliato G, Modorati G, Bandello F. Review on the worldwide epidemiology of uveitis. Eur J Ophthalmol. 2013;23(5):705-717. https://doi. org/https://doi.org/10.5301/ejo.5000278, Available from: Review on the Worldwide Epidemiology of Uveitis.

4. Richard Al. Monocular blindness in Bayelsa state of Nigeria. Pan Afr Med J. 2010;4:6. Available from: http://dx.doi.org/https://doi.org/10.4314/pamj.v4i1. 53607

5. Potter AR. Causes of blindness and visual handicap in the Central African Republic. Br J Ophthalmol 1991;75(6):326-328. Available from: http://dx.doi. org/https://doi.org/10.1136/bjo.75.6.326

6. Sherwin JC, Dean WH, Metcalfe NH. Causes of blindness at Nkhoma eye hospital, Malawi. Eur J Ophthalmol 2008;18(6):1002-1006. Available from: http://dx.doi.org/10.1177/112067210801800624

7. Carreras FJ, Rodríguez-Hurtado F, David H. Ophthalmology in Luanda (Angola): a hospital based report. Br J Ophthalmol 1995;79(10):926-933. Available from: http://dx.doi.org/https://doi.org/10.1136/bjo.79.10.926

8. Statistics South Africa; Profile of persons living with disability 2016 https:// www.statssa.gov.za/publications/P03012016 Accessed October 2019.

9. London NJS, Rathinam SR, Cunningham ET Jr. The epidemiology of uveitis in developing countries. Int Ophthalmol Clin 2010;50(2):1-17. Available from: http://dx.doi.org/https://doi.org/10.1097//I0.0b013e3181d2cc6b

10. Wade PD, Ramyil AV. Aetiology of Uveitis in the Gambia, West Africa. J Ophthalmol Eastern Central Southern Afr. 2015;19(1):4-8.

11. Schaftenaar E, Meenken C, Baarsma GS, Khosa NS, Luijendijk A, McIntyre JA, et al. Uveitis is predominantly of infectious origin in a high HIV and TB prevalence setting in rural South Africa. Br J Ophthalmol 2016;100(10):13121316. Available from: http://dx.doi.org/https://doi.org/10.1136/bjophtha Imol-2016-308645

12. Ronday MJ, Stilma JS, Barbe RF, McElroy WJ, Luyendijk L, Kolk AH, et al. Aetiology of uveitis in Sierra Leone, West Africa. Br J Ophthalmol 1996; 80(11):956-961. Available from: http://dx.doi.org/https://doi.org/10.1136/bjo. 80.11 .956 
13. Tinley C, Van Zyl L, Grötte R. Poststreptococcal syndrome uveitis in South African children. Br J Ophthalmol 2012;96(1):87-89. Available from: http://dx. doi.org/https://doi.org/10.1136/bjo.2010.199315

14. Chinniah K, Mody GM, Bhimma R, Adhikari M. Arthritis in association with human immunodeficiency virus infection in black African children: causal or coincidental? Rheumatology 2005;44(7):915-920. Available from: http://dx. doi.org/https://doi.org/10.1093/rheumatology/keh636

15. Zaborowski AG, Parbhoo D, Chinniah K. Uveitis in children with human immunodeficiency virus-associated arthritis. J AAPOS. 2008;12(6):608-10. https://doi.org/10.1016/j.jaapos.2008.04.011

16. Rautenbach W, Steffen J, Smit D, Lecuona K, Esterhuizen T. Patterns of Uveitis at two University-based referral Centres in Cape Town, South Africa. Ocul Immunol Inflamm 2019;27(6):868-874. Available from: http://dx.doi. org/https://doi.org/10.1080/09273948.2017.1391954

17. Chronopoulos A, Roquelaure D, Souteyrand G, Seebach JD, Schutz JS, Thumann G. Aqueous humor polymerase chain reaction in uveitis--utility and safety. BMC Ophthalmol. 2016;16(1):189. Available from: https://link. springer.com/article/https://doi.org/10.1186/s12886-016-0369-z

18. Damato EM, Angi M, Romano MR, Semeraro F, Costagliola C. Vitreous analysis in the management of uveitis. Mediators Inflamm. 2012;2012: 863418. Available from: http://dx.doi.org/https://doi.org/10.1155/2012/86341 8

19. Haffejee IE, Raga J, Coovadia HM. Juvenile chronic arthritis in black and Indian South African children. S Afr Med J. 1984;65(13):510-4 Available from: https://www.ncbi.nlm.nih.gov/pubmed/6710254.

20. Chipeta J, Njobvu P, Wa-Somwe S, Chintu C, McGill PE, Bucala R. Clinical patterns of juvenile idiopathic arthritis in Zambia. Pediatr Rheumatol Online J;11(1):33. Available from: http://dx.doi.org/https://doi.org/10.1186/15460096-11-33

21. Adelowo OO, Umar A. Juvenile idiopathic arthritis among Nigerians: a case study. Clin Rheumatol 2010;29(7):757-761. Available from: http://dx.doi.org/ https://doi.org/10.1007/s10067-010-1401-y

22. Olaosebikan BH, Akintayo RO, Animashaun BA, Adelowo OO. Juvenile idiopathic Arthritis in a new rheumatology Clinic in Nigeria. JARS Open Access Pub. 2017;1(1):1.

23. Khairallah M, Yahia SB, Ladjimi A, Messaoud R, Zaouali S, Attia S, Jenzeri S, Jelliti B Pattern of uveitis in a referral Centre in Tunisia, North Africa. Eye 2007;21(1):33-39. Available from: http://dx.doi.org/https://doi.org/10.1038/sj. eye.6702111

24. Allali F, Benomar A, Karim A, Lazrak N, Mohcine Z, El Yahyaoui M, et al. Behçet's disease in Moroccan children: a report of 12 cases. Scand J Rheumatol 2004;33(5):362-363. Available from: http://dx.doi.org/https://doi. org/10.1080/03009740410005980

25. Khairallah M, Accorinti M, Muccioli C, Kahloun R, Kempen JH. Epidemiology of Behçet disease. Ocul Immunol Inflamm 2012;20(5):324-335. Available from: http://dx.doi.org/https://doi.org/10.3109/09273948.2012.723112

26. Jari M, Shiari R, Salehpour O, Rahmani K. Epidemiological and advanced therapeutic approaches to treatment of uveitis in pediatric rheumatic diseases: a systematic review and meta-analysis. Orphanet J Rare Dis. 2020; 15(1):41. Available from: http://dx.doi.org/https://doi.org/10.1186/s13023-02 $0-1324-x$

27. Angeles-Han ST, McCracken C, Yeh S, Jenkins K, Stryker D, Rouster-Stevens K, et al. Characteristics of a cohort of children with Juvenile Idiopathic Arthritis and JIA-associated Uveitis. Pediatr Rheumatol Online J. 2015;13:19. Available from: http://dx.doi.org/https://doi.org/10.1186/s12969-015-0018-8

28. Angeles-Han ST, Yeh S, Vogler LB. Updates on the risk markers and outcomes of severe juvenile idiopathic arthritis-associated uveitis. Int J Clin Rheumtol. 2013;8(1). Available from: http://dx.doi.org/https://doi.org/10.221 7/ijr.12.83

29. Angeles-Han ST, McCracken C, Yeh S, Jenkins K, Stryker D, Travers C, et al. The association of race with childhood uveitis. Am J Ophthalmol. 2015; 160(5):919-28.e1. Available from: http://dx.doi.org/https://doi.org/10.1016/j.a jo.2015.08.002

30. Butbul Aviel Y, Tyrrell P, Schneider R, Dhillon S, Feldman BM, Laxer R, et al. Juvenile Psoriatic Arthritis (JPsA): juvenile arthritis with psoriasis? Pediatr Rheumatol Online J. 2013;11(1):11. : https://doi.org/https://doi.org/10.1186/1 546-0096-11-11, Available from Juvenile Psoriatic Arthritis (JPsA): juvenile arthritis with psoriasis?

31. Castagna I, Roszkowska AM, Alessandrello F, Oliverio GW, Tumminello G, Gallizzi R, Conti G, Aragona P Juvenile idiopathic arthritis-associated uveitis: a retrospective analysis from a Centre of South Italy. Int Ophthalmol 2020;
40(2):335-342. Available from: http://dx.doi.org/https://doi.org/10.1007/s1 0792-019-01184-8

32. Heiligenhaus A, Heinz C, Edelsten C, Kotaniemi K, Minden K. Review for disease of the year: epidemiology of juvenile idiopathic arthritis and its associated uveitis: the probable risk factors. Ocul Immunol Inflamm 2013;21(3):180-191. Available from: http://dx.doi.org/https://doi.org/10.3109/09273948.2013.791701

33. Khairallah M. Are the standardization of the Uveitis nomenclature (SUN) working group criteria for codifying the site of inflammation appropriate for all uveitis problems? Limitations of the SUN working group classification. Ocul Immunol Inflamm 2010;18(1):2-4. Available from: https://www. tandfonline.com/doi/abs/https://doi.org/10.3109/09273940903348835

34. Jabs DA, Nussenblatt RB, Rosenbaum JT. Others. Standardization of Uveitis nomenclature (SUN) working group. Standardization of uveitis nomenclature for reporting clinical data. Results of the first international workshop. Am J Ophthalmol. 2005;140(3):509-16. https://doi.org/10.1016/j.a jo.2005.03.057.

35. Constantin T, Foeldvari I, Anton J, de Boer J, Czitrom-Guillaume S, Edelsten C, et al. Consensus-based recommendations for the management of uveitis associated with juvenile idiopathic arthritis: the SHARE initiative. Ann Rheum Dis 2018;77(8):1107-1117. Available from: http://dx.doi.org/https://doi.org/1 0.1136/annrheumdis-2018-213131

36. Angeles-Han ST, Ringold S, Beukelman T, Lovell D, Cuello CA, Becker ML, Colbert RA, Feldman BM, Holland GN, Ferguson PJ, Gewanter H, Guzman J, Horonjeff J, Nigrovic PA, Ombrello MJ, Passo MH, Stoll ML, Rabinovich CE, Sen HN, Schneider R, Halyabar O, Hays K, Shah AA, Sullivan N, Szymanski AM, Turgunbaev M, Turner A, Reston J 2019 American College of Rheumatology/Arthritis Foundation guideline for the screening, monitoring, and Treatment of Juvenile idiopathic Arthritis-associated Uveitis. Arthritis Care Res 2019;71(6):703-716. Available from: http://dx.doi.org/https://doi. org/10.1002/acr.23871

37. Heiligenhaus A, Minden K, Tappeiner C, Baus H, Bertram B, Deuter C, Foeldvari I, Föll D, Frosch M, Ganser G, Gaubitz M, Günther A, Heinz C, Horneff G, Huemer C, Kopp I, Lommatzsch C, Lutz T, Michels H, Neß T, Neudorf U, Pleyer U, Schneider M, Schulze-Koops H, Thurau S, Zierhut M, Lehmann HW Update of the evidence based, interdisciplinary guideline for anti-inflammatory treatment of uveitis associated with juvenile idiopathic arthritis. Semin Arthritis Rheum 2019;49(1):43-55. Available from: http://dx doi.org/https://doi.org/10.1016/j.semarthrit.2018.11.004

38. Wulffraat NM, Vastert B, SHARE consortium. Time to share. Pediatr Rheumatol Online J. 2013;11(1):5. Available from: http://dx.doi.org/https:// doi.org/10.1186/1546-0096-11-5

39. Ramanan AV, Dick AD, Jones AP, McKay A, Williamson PR, CompeyrotLacassagne S, Hardwick B, Hickey H, Hughes D, Woo P, Benton D, Edelsten C, Beresford MW Adalimumab plus methotrexate for Uveitis in Juvenile idiopathic Arthritis. N Engl J Med 2017;376(17):1637-1646. Available from: http://dx.doi.org/https://doi.org/10.1056/NEJMoa1614160

40. Quartier P, Baptiste A, Despert V, Allain-Launay E, Koné-Paut I, Belot A Kodjikian L, Monnet D, Weber M, Elie C, Bodaghi B, ADJUVITE Study Group. ADJUVITE: a double-blind, randomised, placebo-controlled trial of adalimumab in early onset, chronic, juvenile idiopathic arthritis-associated anterior uveitis. Ann Rheum Dis 2018:77(7):1003-1011. Available from: http://dx.doi.org/https://doi.org/10.1136/annrheumdis-2017-212089

41. Miserocchi E, Modorati G, Berchicci L, Pontikaki I, Meroni P, Gerloni V. Longterm treatment with rituximab in severe juvenile idiopathic arthritisassociated uveitis. Br J Ophthalmol 2016;100(6):782-786. Available from: http://dx.doi.org/https://doi.org/10.1136/bjophthalmol-2015-306790

42. Heiligenhaus A, Miserocchi E, Heinz C, Gerloni V, Kotaniemi K. Treatment of severe uveitis associated with juvenile idiopathic arthritis with anti-CD20 monoclonal antibody (rituximab). Rheumatology 2011;50(8):1390-1394. Available from: http://dx.doi.org/https://doi.org/10.1093/rheumatology/ker107

43. Kenawy N, Cleary G, Mewar D, Beare N, Chandna A, Pearce I. Abatacept: a potential therapy in refractory cases of juvenile idiopathic arthritisassociated uveitis. Graefes Arch Clin Exp Ophthalmol 2011;249(2):297-300. Available from: http://dx.doi.org/https://doi.org/10.1007/s00417-010-1523-6

44. Tappeiner C, Mesquida M, Adán A, Anton J, Ramanan AV, Carreno E, Mackensen F, Kotaniemi K, de Boer JH, Bou R, de Vicuña CG, Heiligenhaus A Evidence for Tocilizumab as a Treatment option in refractory Uveitis associated with Juvenile idiopathic Arthritis. J Rheumatol 2016;43(12):2183-2188. Available from: http://dx.doi.org/https://doi.org/10.3899/jrheum.160231

45. Lopalco G, Fabiani C, Sota J, Lucherini OM, Tosi GM, Frediani B, lannone F, Galeazzi M, Franceschini R, Rigante D, Cantarini L IL-6 blockade in the 
management of non-infectious uveitis. Clin Rheumatol 2017;36(7):1459-1469. Available from: http://dx.doi.org/https://doi.org/10.1007/s10067-017-3672-z

46. Gaggiano C, Rigante D, Tosi GM, Vitale A, Frediani B, Grosso S, Fabiani C, Cantarini $L$ Treating juvenile idiopathic arthritis (JIA)-related uveitis beyond TNF-a inhibition: a narrative review. Clin Rheumatol 2020;39(2):327-337. Available from: http://dx.doi.org/https://doi.org/10.1007/s10067-019-04763-3

47. Stats SA. Statistics South Africa. Formal census [Internet]. 2011; Available from: http://www.treasury.gov.za/documents/national\%20budget/2002/ene/ vote_13.pdf. Accessed October 2019.

48. Clarke SLN, Sen ES, Ramanan AV. Juvenile idiopathic arthritis-associated uveitis. Pediatr Rheumatol Online J. 2016;14(1):27. Available from: http://dx. doi.org/https://doi.org/10.1186/s12969-016-0088-2

49. Schulze-Bonsel K, Feltgen N, Burau H, Hansen L, Bach M. Visual acuities "hand motion" and "counting fingers" can be quantified with the freiburg visual acuity test. Invest Ophthalmol Vis Sci 2006;47(3):1236-1240. Available from: http://dx.doi.org/https://doi.org/10.1167/iovs.05-0981

50. Petty RE, Southwood TR. Pediatric rheumatology-ILAR classification of JIA: second revision, Edmonton, 2001. J Rheumatol. 2004;31:390-2.

51. Koné-Paut I. Behçet's disease in children, an overview. Pediatr Rheumatol Online J. 2016;14(1):10. Available from: http://dx.doi.org/https://doi.org/10.11 86/s12969-016-0070-z

52. Nussenblatt RB, Palestine AG, Chan C-C, Roberge F. Standardizatlon of Vitreal inflammatory activity in intermediate and posterior Uveitis. Ophthalmology. 1985;92(4):467-71. Available from: http://www. sciencedirect.com/science/article/pii/S0161642085340010. https://doi.org/1 0.1016/S0161-6420(85)34001-0

53. Busch M, Wefelmeyer KL, Walscheid K, Rothaus K, Bauer D, Deeg CA, et al. Identification of ocular autoantigens associated with juvenile idiopathic arthritis-associated uveitis. Front Immunol. 2019;10:1793. Available from: http://dx.doi.org/https://doi.org/10.3389/fimmu.2019.01793

54. Vastert SJ, Bhat P, Goldstein DA. Pathophysiology of JIA-associated uveitis. Ocul Immunol Inflamm 2014;22(5):414-423. Available from: http://dx.doi. org/https://doi.org/10.3109/09273948.2014.926937

55. Weakley K, Esser M, Scott C. Juvenile idiopathic arthritis in two tertiary centres in the Western Cape, South Africa. Pediatr Rheumatol Online $J$ 2012;10(1):35. Available from: http://dx.doi.org/https://doi.org/10.1186/15460096-10-35

56. Olaosebikan BH, Adelowo OO, Animashaun BA, Akintayo RO. Spectrum of paediatric rheumatic diseases in Nigeria. Pediatr Rheumatol Online J. 2017; 15(1):7. Available from: http://dx.doi.org/https://doi.org/10.1186/s12969-0170139-3

57. Furia FF, Godfrey E, Mwamanenge N, Swai P. spectrum of paediatric rheumatic disorders at a tertiary hospital in Tanzania. Pediatr Rheumatol Online J. 2020;18(1):30. Available from: http://dx.doi.org/https://doi.org/10.11 86/s12969-020-0418-2

58. Bhimma R, Coovadia HM, Adhikari M. Improved outcome of systemic lupus erythematosus among children in Durban, South Africa. Ann Trop Paediatr 1994;14(2):119-124. Available from: http://dx.doi.org/https://doi.org/10.1080/ 02724936.1994 .11747703

59. Mayosi BM, Flisher AJ, Lalloo UG, Sitas F, Tollman SM, Bradshaw D. The burden of non-communicable diseases in South Africa. Lancet 2009; 374(9693):934-947. Available from: http://dx.doi.org/https://doi.org/10.1016/ S0140-6736(09)61087-4

60. Mayosi BM, Benatar SR. Health and health care in South Africa - 20 years after mandela. N Engl J Med. 2014;371(14):1344-1353. https://doi.org/ https://doi.org/10.1056/NEJMsr1405012, Available from: Health and Health Care in South Africa - 20 Years after Mandela.

61. Lee JJY, Duffy CM, Guzman J, Oen K, Barrowman N, Rosenberg AM, Shiff NJ, Boire G, Stringer E, Spiegel L, Morishita KA, Lang B, Reddy D, Huber AM, Cabral DA, Feldman BM, Yeung RSM, Tucker LB, Watanabe Duffy K, for the ReACCh-Out Investigators Prospective determination of the incidence and risk factors of new-onset Uveitis in Juvenile idiopathic Arthritis: the research in Arthritis in Canadian children emphasizing outcomes cohort. Arthritis Care Res 2019;71(11):1436-1443. Available from: http://dx.doi.org/https://doi. org/10.1002/acr.23783

62. Heiligenhaus A, Minden K, Föll D, Pleyer U. Uveitis in juvenile idiopathic arthritis. Dtsch Arztebl Int 2015;112(6):92-100, i. Available from: http://dx.doi. org/https://doi.org/10.3238/arztebl.2015.0092

63. Oyoo GO, Genga EK, Otieno FO, Omondi EA. Clinical patterns of juvenile idiopathic arthritis: a single tertiary center experience in Kenya. Afr J
Rheumatol (AFLAR). 2016;4(2):66-71 Available from: https://www.researchga te.net/publication/306057270.

64. Abd El Latif E, Fayez Goubran W, El Gemai EEDM, Habib AE, Abdelbaki AM, Ammar $\mathrm{H}$, et al. Pattern of childhood uveitis in Egypt. Ocul Immunol Inflamm. 2019;27(6):883-889. Available from: http://dx.doi.org/https://doi. org/10.1080/09273948.2018.1502325

65. Freedman J. Incidence of uveitis in bantu-speaking negroes of South Africa. Br J Ophthalmol 1974;58(6):595-599. Available from: http://dx.doi.org/ https://doi.org/10.1136/bjo.58.6.595

66. Freedman J. Anterior uveitis in bantu children. Br J Ophthalmol 1973;57(5): 355-358. Available from: http://dx.doi.org/10.1136/bjo.57.5.355

67. Pasadhika S, Rosenbaum JT. Ocular Sarcoidosis. Clin Chest Med 2015;36(4): 669-683. Available from: http://dx.doi.org/https://doi.org/10.1016/j.ccm.2015 08.009

68. Morelle G, Gueudry J, Uettwiller F, Wouters C, Bader-Meunier B, Robert MP, et al. Chronic and recurrent non-infectious paediatric-onset uveitis: a French cohort. RMD Open. 2019;5(2):e000933. Available from: http://dx.doi.org/ https://doi.org/10.1136/rmdopen-2019-000933

69. Wouters $\mathrm{CH}$, Maes A, Foley KP, Bertin J, Rose CD. Blau syndrome, the prototypic auto-inflammatory granulomatous disease. Pediatr Rheumatol Online J. 2014;12:33. Available from: http://dx.doi.org/https://doi.org/10.11 86/1546-0096-12-33

70. Nathan N, Marcelo P, Houdouin V, Epaud R, de Blic J, Valeyre D, Houzel A, Busson PF, Corvol H, Deschildre A, Clement A Lung sarcoidosis in children: update on disease expression and management. Thorax 2015;70(6):537-542. Available from: http://dx.doi.org/https://doi.org/10.1136/thoraxjnl-2015-2 06825

71. Hoover DL, Khan JA, Giangiacomo J. Pediatric ocular sarcoidosis. Surv Ophthalmol 1986;30(4):215-228. Available from: http://dx.doi.org/https://doi. org/10.1016/0039-6257(86)90118-9

72. Ajose FOA, Adelowo O, Oderinlo O. Clinical presentations of Behçet's disease among Nigerians: a 4-year prospective study. Int J Dermatol 2015; 54(8):889-897. Available from: http://dx.doi.org/https://doi.org/10.1111/ijd.12 554

73. Ghembaza MEA, Lounici A. Relationship between age at onset and clinical characteristics of Behçet's disease. Acta Dermatovenerol Alp Pannonica Adriat. 2018;27(4):175-7 Available from: https://www.ncbi.n/m.nih.gov/ pubmed/30564829.

74. Kilmartin DJ, Forrester JV, Dick AD. Cyclosporin a therapy in refractory noninfectious childhood uveitis. Br J Ophthalmol 1998;82(7):737-742. Available from: http://dx.doi.org/https://doi.org/10.1136/bjo.82.7.737

75. Mathews D, Mathews J, Jones NP. Low-dose cyclosporine treatment for sight-threatening uveitis: efficacy, toxicity, and tolerance. Indian J Ophthalmol 2010;58(1):55-58. Available from: http://dx.doi.org/https://doi. org/10.4103/0301-4738.58472

76. Cecchin V, Zannin ME, Ferrari D, Pontikaki I, Miserocchi E, Paroli MP, Bracaglia C, Marafon DP, Pastore S, Parentin F, Simonini G, de Libero C, Falcini F, Petaccia A, Filocamo G, de Marco R, la Torre F, Guerriero S, Martino S, Comacchio F, Muratore V, Martini G, Vittadello F, Zulian F Longterm safety and efficacy of Adalimumab and infliximab for Uveitis associated with Juvenile idiopathic Arthritis. J Rheumatol 2018;45(8):1167-1172. Available from: http://dx.doi.org/https://doi.org/10.3899/jrheum.171006

77. Simonini G, Taddio A, Cattalini M, Caputo R, De Libero C, Naviglio S, et al. Prevention of flare recurrences in childhood-refractory chronic uveitis: an open-label comparative study of adalimumab versus infliximab. Arthritis Care Res 2011;63(4):612-618. Available from: http://dx.doi.org/https://doi. org/10.1002/acr.20404

78. Gamalero L, Simonini G, Ferrara G, Polizzi S, Giani T, Cimaz R. Evidencebased treatment for uveitis. Isr Med Assoc J. 2019;21(7):475-9 Available from: https://www.ncbi.nlm.nih.gov/pubmed/31507124.

\section{Publisher's Note}

Springer Nature remains neutral with regard to jurisdictional claims in published maps and institutional affiliations. 